\title{
Pitääkö yrittäjän elää yrittäjän elämä?
}

\section{Näkökulmia maahanmuuttajien yrittäjyyskoulutuksen suunnitteluun ja toteutukseen}

\author{
$+y$ \\ Yrittäjäksi ryhtyminen edellyttää maahanmuuttajalta \\ tietojen ja taitojen ohella syvää oman identiteetin \\ pohdintaa. Millä tavoin koulutusorganisaatiot voivat \\ tukea yrittäjyydestä kiinnostuneita maahanmuuttajia?
}

YRITTÄJYYSKOULUTUSTA ON PIDETTY keskeisenä ratkaisuna maahanmuuttajien työllisyyden parantamiseen ja keinona saada heidän taitonsa ja osaamisensa yhä paremmin yhteiskunnan käyttöön. Yrittäjyyden kautta on myös mahdollista kohentaa maahanmuuttajien taloudellista tilannetta. Se voi auttaa luomaan sosiaalisia verkostoja ja tukea uuteen kotimaahan integroitumista (Fong ym. 2007; Kloosterman 2010).

Maahanmuuttajayrittäjillä voi olla erityisosaamista, joka kumpuaa heidän valtaväestöstä poikkeavasta taustastaan. Taustansa vuoksi he pystyvät täyttämään markkinarakoja, jotka muuten jäisivät katveeseen, ja tukemaan osaltaan kansallista innovaatiopolitiikkaa (Ma ym. 2013; Sahin ym. 2014).
Euroopan unioni määrittelee maahanmuuton asuinmaan väliaikaisena tai pysyvänä vaihtamisena. Se on useissa aloitteissaan korostanut tarvetta poistaa esteitä maahanmuuttajayrittäjien tieltä (Euroopan komissio 2016). Unionin jäsenvaltioiden tulisi erityisesti lisätä tietoisuutta maahanmuuttajien potentiaalista osana kansallisia talousjärjestelmiä. Yrittäjyyden polku on kuitenkin vaativa, ja yrittäjyys on riskipitoista toimintaa, johon ryhtyminen edellyttää sekä koulutuksellista että henkistä tukea. Keskeinen kysymys kouluttajien ja rahoittajien näkökulmasta on, millä tavoin maahanmuuttajia voidaan parhaiten tukea yrittäjyyden polulla. 


\section{ELÄMÄNTARINOIDEN}

\section{TUNNISTAMINEN TAI}

TUNNUSTAMINEN KOROSTAA

\section{EMPAATTISUUDEN}

\section{MERKITYSTÄ KOULUTUKSEN}

\section{TOTEUTUKSESSA.}

Nostamme esiin maahanmuuttajien yrittäjyyskoulutukseen liittyviä näkökulmia, jotka pohjautuvat "MEGE - multicultural encounters, growth and entrepreneurship" -projektissa kerättyihin kokemuksiin. MEGE (www.mege.fi) oli vuosina 2017-2020 toteutettu hanke, jonka tavoite oli hyödyntää maahanmuuttajien osaamista suomalaisessa yhteiskunnassa. Se pyrki tavoitteisiinsa tukemalla erityisesti uusien, kasvuhakuisten yritysten syntymistä ja omistajanvaihdoksia. MEGE-hankkeessa yhdistyi neljän pääkaupunkiseudulla toimivan koulutusorganisaation osaaminen. Projektin toteuttivat Haaga-Helia, Business College Helsinki, The Shortcut ja Aaltoyliopisto. Hankkeen rahoitti Helsinki-Uudenmaan liitto Euroopan aluekehitysrahastosta (EAKR).

Toteuttajat keräsivät hankkeen keston ajan sekä määrällistä että laadullista tietoa. Hankekumppanit seurasivat koulutuksiin osallistujien ja perustettujen yritysten ja yritysvaihdosten lukumäärän kehitystä ja vertasivat hankkeen koulutustarjontaa muihin vastaaviin koulutuksiin. Tietoja täydennettiin laadullisella tiedonkeruulla, joka sisälsi sarjan kaikille osallistujille lähetettyjä kyselyjä sekä syvähaastatteluja noin 30 osallistujan kanssa hankkeen alku-, keski- ja loppuvaiheissa. Näiden avulla voitiin ymmärtää koulutukseen osallistujien elämäntilannetta ja profiilia, tunnistaa heidän tarpeitaan ja haasteitaan sekä seurata heidän edistymistään yrittäjän polulla. Lisäksi projektin koulutustilaisuuksissa ja tapahtumissa havainnointiin osallistujia ja kerättiin heiltä palautetta. Kerättyä tietoa käsiteltiin yhteisissä työpajoissa projektin palvelutarjonnan kehittämiseksi ja siitä viestitiin sekä aikuiskouluttajille että yrittäjyyskoulutuksen tutkijoille.
MEGE-projektin toteuttaneet koulutusorganisaatiot kokevat, että yrittäjäksi kasvaminen on ihmisenä kasvamista. Maahanmuuttajien yrittäjyyden kokonaisvaltainen tukeminen korostui covid-19-pandemian aiheuttamassa, yksilöihin ja talouteen kohdistuneessa kriisissä.

\section{YRITTÄJYYS OSAKSI OMAA ELÄMÄNTARINAA}

Hankkeen toteutuksessa korostui osallistujien yksilöllisten elämäntilanteiden moninaisuus. Elämäntilanne on konteksti, josta käsin henkilö ponnistaa yrittäjyyteen, ja jota yrittäjyys muuttaa (Obschonka 2018). Esimerkiksi yliopisto-opiskelijat ovat usein selvästi homogeenisempi ryhmä kuin kaikille - kansainvälisen taustan omaaville - avoimiin MEGEkoulutuksiin osallistuneiden joukko.

Menestyksekäs yrittäjyyskoulutus edellyttää, että sen järjestävässä koulutusorganisaatiossa tiedetään osallistujien taustat. Onko osallistuja saapunut Suomeen koulutusmahdollisuuksien tai esimerkiksi puolison perässä, jolloin hänellä on sosiaalisia verkostoja maassa? Vai onko osallistuja tullut Suomeen osittain traumatisoituneena, vaikean elämäntilanteen siivittämänä, esimerkiksi pakolaisstatuksella sota-alueelta? Taustatekijät ja Suomessa vietetty aika vaikuttavat kriittisesti siihen, kuinka myönteiseksi ja varmaksi henkilö tuntee olonsa ja kuinka valmis hän on ottamaan riskejä uudessa kotimaassaan. Perhetilanne ja kulttuurinen tausta voivat lisäksi vaikuttaa siihen, kuinka paljon oma lähipiiri tukee yrittäjäksi ryhtymistä (Rath 2011).

Yksilökohtaisella tavoitteella on samoin tärkeä merkitys: haetaanko yrittäjäksi ryhtymisellä esimerkiksi taloudellista menestystä jo olemassa olevaa pääomaa hyödyntäen vai perustoimeentuloa päivittäiseen selviytymiseen?

MEGE-hankkeen osallistujille liiketoimintamahdollisuuksien hyödyntäminen oli harvoin ensisijainen motiivi ryhtyä yrittäjäksi. Keskeisenä syynä esille nousi halu osallistua ja tuottaa yhteiskunnallisesti merkityksellisiä tuloksia: tarjota tuotteita ja palveluja, jotka voisivat auttaa itselle tärkeää asiakaskuntaa, luoda työpaikkoja sekä parantaa ympäristön ja yhteiskunnan hyvinvointia. Toinen tärkeä 


\section{MaAhanmUUtTajia VoidaAn}

ROHKAISTA N $\ddot{A} K E M \ddot{A A} N$

YHÄ PAREMMIN OMIA

YKSILÖLLISI ̈̈ PIIRTEIT $\ddot{A} \ddot{A}$

JA SANALLISTAMAAN NIIDEN

VAHVUUKSIA JA HEIKKOUKSIA.

motiivi oli oman osaamisen ja potentiaalin täysimäräinen hyödyntäminen, kun työmarkkinoilla oli saatavilla ainoastaan alhaista osaamista vaativia työtehtäviä. Useilla palo yrittäjyyteen ja yrittäjämäinen identiteetti olivat kasvaneet sisimmässä pitkään, mikä on yleistä yrittäjyyskoulutukseen osallistuvilla (Liñán ym. 2018).

Aiempi koulutus ja työkokemus ovat keskeisiä yksilön elämäntarinassa. Vaikka julkisessa keskustelussa saatetaan arvioida maahanmuuttajien koulutustaustaa ryhmätasolla eli tarkastella, millainen koulutustausta ja kyvykkyydet eri kansallisuuksien edustajilla on (Adecco 2017; Deloitte 2017), tilastoilla ei ole yksilön toiminnan kannalta merkitystä. Maasta toiseen muuttaminen edellyttää yksilöltä usein joustavuutta työmarkkinoilla, minkä vuoksi maahanmuuttajille on voinut kertyä osaamista monelta toimialalta ja eri tehtävistä. Tämän potentiaalin hyödyntäminen ja syvempi ymmärrys - koulutustodistuksia painottavan lähestymistavan sijaan on ensiarvoista Suomen yrittäjyyskentän kestävälle kehitykselle. Koulutustarjonnan suunnittelijat sekä valmentajat, mentorit ja kouluttajat voivat auttaa osallistujia hahmottamaan oman tarinansa ja pohtimaan, millä tavoin yrittäjäksi ryhtyminen muuttaisi tulevaisuuden suuntaa.

Elämäntarinoiden tunnistaminen tai tunnustaminen korostaa empaattisuuden tärkeyttä koulutuksen toteutuksessa. Yrittäjyyskoulutukselta odotetaan usein konkreettisia, ainoastaan numeroihin perustuvia hyötylaskelmia (Duval-Couetil 2013). Nämä mittarit eivät huomioi muutoksia henkisessä hyvinvoinnissa tai mittaa yhteiskuntaan integroitumista (Donnellon ym. 2014; Jensen, 2014; Luke ym.2007). Samalla jää varjoon se, että yrittäjyyteen ryhtymisen esteinä voi olla konkreettisia, yksilön elämäntilannetta koskevia tekijöitä, kuten ajankäyttö tai muuttunut perhetilanne, joita ei voida ratkaista koulutuksella (Rath 2011).

\section{UUSI YRITTÄJÄN MINÄKUVA}

Yrittäjien ajatellaan tyypillisesti olevan dynaamisia, rohkeita, ulospäinsuuntautuneita ja sankarimaisia nuoria miehiä (Ferry ym. 2018; Laine \& Kibler 2018). Mediassa menestyvinä yrittäjinä esiintyvät yrittäjyydessä menestyneet henkilöt, kuten Ryanairin perustaja Michael O'Leary (Anderson \& Warren 2011). Tästä voi syntyä käsitys, että kaikkien yrittäjäksi haluavien pitäisi löytää sisältään samanlainen sankaripersoona. Yrittäjän identiteetti voi kuitenkin olla sankarin ohella hyvin humaani (Hytti \& Heinonen 2013).

Itsetuntemus ja omien vahvuuksien tunnistaminen nousivat hankkeessa yrittäjyyden perustaksi. Kun yrittäjäksi haluavat tuntee itsensä paremmin, he voivat löytää uniikkeja piirteitä, joista on hyötyä yrittäjänä. Henkilökohtaisen reflektion tukeminen yrittäjyyskoulutuksessa auttaa yrittäjyyttä harkitsevaa tunnistamaan heikkoutensa ja sitä kautta huomaamaan yhteistyön ja tuen tarpeensa. MEGE-hankkeen valmennuksiin osallistuneet maahanmuuttajat toivat esille yrittäjyyttä tukevina luonteenpiirteinään muun muassa taidon kuunnella sekä kekseliäisyyden ja intohimon. Eräs osallistuja totesi: "En ole yhtään yrittäjähenkinen, mutta varmasti onnistuisin, koska teen kaiken aina päättäväisesti ja kunnolla."

Maahanmuuttajia voidaan rohkaista näkemään yhä paremmin omia yksilöllisiä piirteitään ja etenkin sanallistamaan niiden sisältämiä vahvuuksia ja heikkouksia. Tämä auttaa henkilöä kehittämään identiteettiään ja näkemään itsensä tulevana yrittäjänä (Donnellon ym. 2014). Samaan aikaan yrittäjyyteen ryhtyvän on "opittava pois" tietystä roolista, jossa hän on aiemmin toiminut tai odottaa toimivansa menneisyytensä perusteella. Moni maahanmuuttaja on voinut uuteen maahan muutettuaan työskennellä selvästi omaa taitotasoaan yksinkertaisemmissa tehtävissä. Yrittäjäksi ryhtyminen edellyttää, että he näkevät itsensä uudella tavalla ja osaavat esittäytyä 
muille ihmisille uudessa sosiaalisessa asemassaan yrittäjinä.

Aiempi tutkimus viittaa siihen, että henkisen ja sosiaalisen pääoman kasvattamisella on selkeästi tärkeämpi merkitys yrittäjyyskoulutuksessa kuin varsinaisten liiketoimintatietojen ja -taitojen kartuttamisella (Bechard \& Gregoire 2005; Gomez ym. 2020). Henkisiä valmiuksia voidaan korostaa esimerkiksi mindfulness-koulutusten ja muiden henkilökohtaiseen reflektointiin liittyvien työkalujen avulla. Tutkimusnäyttö osoittaa, että jo tunnin mittaisella päivittäisellä meditaatiolla pystyttiin vähentämään epäonnistumisen pelkoa yrittäjien keskuudessa (Engel ym. 2019).

\section{OIKEAT IHMISET YMPÄRILLÄ}

MEGE-projektin kokemusten perusteella on syytä korostaa yhteisön merkitystä. Vaikka monella yrittäjyydestä kiinnostuneella voi olla paljonkin muita velvoitteita, haastatellut kaipasivat vuorovaikutusta sekä samassa tilanteessa olevien että itseään kokeneempien yrittäjien ja mentoreiden kanssa. Koulutuksen järjestäjien on siksi keskeistä nähdä yrittäjyyskoulutuksen tarjoaminen muunakin kuin perinteisenä, tietyn formaatin täyttävänä "palvelupakettina". Ennen kaikkea koulutusorganisaatioiden tulisi luoda yhteisö, joka tukee uusien kontaktien syntymistä ja auttaa lieventämään stressiä, kun yrittäjyydessä on haasteita.

Verkostot tukevat liiketoiminnan kehittämistä, ja moni yhteisön jäsen toivoo löytävänsä verkostosta liikekumppaneita tai sijoittajia. Yrittäjyyskoulutukseen osallistuneet maahanmuuttajat haluavat saada vertaistietoa paikallisista käytännöistä ja pohtia yhdessä, millainen palvelu ja lähestymistapa vetoaisi asiakkaisiin (Spiegel 2017). Näihin tarpeisiin vastaavat parhaiten yrittäjyyden alalla toimivat yhdistykset ja kaikille avoimet tilaisuudet.

Yhteisöltä odotetaan ennen kaikkea henkistä tukea ja jotain, mikä ravisuttaa ja kehittää omaa ajattelua. Yrittäjän identiteetti ei kehity vain "töissä" vaan kaikenlaisessa vuorovaikutuksessa perheen ja ystävien sekä asiakkaiden, työkavereiden, yhteistyökumppaneiden ja kilpailijoiden kanssa (Rigg \& O’Dwyer 2012).
"Tarvitsen ihmisiä, jotka ajattelevat uudella tavalla, puhtaalta pöydältä, ja osaavat kuvitella jotakin, jota ei vielä ole olemassa”, totesi eräs MEGEhankkeen osallistuja. Tällaisen yhteisön jäsenten osalta liiketoimintatuntemusta tärkeämpää on, että ihmiset luottavat toisiinsa ja uskaltavat keskustella keskeneräisistäkin ajatuksistaan, toiveistaan ja peloistaan avoimesti. Ilmapiirin on sallittava ajoittaiset kielteiset tunteet ja epäonnistumiset. Samalla yhteisön on oltava kannustava ja sellainen, jossa voi jakaa onnistumisiaan ja iloita menestyksestä yhdessä.

Luovan tiimityön yhteydessä on puhuttu 'psykologisesta turvallisuudesta', jolla tarkoitetaan, että jokin yhteisö on turvallinen paikka ottaa yksilöjen välisiä riskejä (Edmondson 1999; Frazier 2017). Psykologisen turvallisuuden käsitettä ei ole yleensä liitetty yrittäjäksi ryhtymisen prosessiin. Vaikka henkilö ei työnsä puolesta toimisikaan tiimissä tai organisaatiossa, voisi hänellä kuitenkin olla ympärillään tällainen turvallinen yhteisö (Salmivaara ym. 2020).

Millä keinoin voidaan luoda yhteisöjä, jotka tukevat paitsi ammatillisten kontaktien luomista myös luovuuden ja rohkeuden kukoistusta? Miten tilojen ilme ja käytännöt vaikuttavat? MEGEprojektin kumppaniorganisaatio The Shortcutissa ollaan aina sukkasillaan, ja jokainen osallistuu tiskikoneen täyttöön. Tämä lisää vuorovaikutusta tiloissa tilapäisesti vierailevien ja siellä pysyvästi työskentelevien yrittäjien välillä.

\section{KOKEMUS KARTTUU ERI YMPÄRISTÖISSÄ}

Filosofi Esa Saarinen puhuu "Filosofia ja systeemiajattelu" -kurssillaan ${ }^{1}$ vaarasta, että pilkomme asioita liiaksi osiin. Jääkiekossa katseemme kiinnittyy siihen, kuka teki maalin ja kuka antoi syötön, mutta jätämme laajemmat, tilanteen kehittymiseen vaikuttaneet tekijät huomiotta. Olennaista olisi kuitenkin ajatella olevansa osa systeemiä, jossa syntyy uutta ajattelua ja tekemistä. Samaa ajatusta voi soveltaa yrittäjyyskoulutuksessa: Mitä yrittäjyys on kokonaisuutena, eri tasoilta tarkasteltuna? Ja miten kokonaisuutta voidaan tukea mahdollisimman oikea-aikaisella ja -sisältöisellä koulutuksella? 
KOKEMUKSET OVAT

SITÄ RIKKAAMPIA, MITÄ

MONINAISIMMISSA

YMPÄRISTÖISS ̈̈ NIT $\ddot{A}$ KER $\ddot{A}$.

Kokonaisvaltainen ote edellyttää, että yrittäjyyttä harkitseva vahvistaa avoimesti monenlaisia tietojaan, taitojaan ja ajattelutapojaan. Näitä voi oppia ja kerryttää luokkahuoneissa ja verkko-oppimisympäristöissä, toimiessaan muiden kanssa yhteistyössä tai pohdiskellessaan päiväänsä yksin. Kokemukset ovat kuitenkin sitä rikkaampia, mitä moninaisimmissa ympäristöissä niitä kerää.

MEGE-projektissa tätä monimuotoisuutta pyrittiin tukemaan järjestämällä koulutusta erilaisissa fyysisissä ja virtuaalisissa tiloissa sekä tarjoamalla mahdollisuuksia epämuodolliseen kanssakäymiseen ja rajojen rikkomiseen. Hankkeen osana järjestettiin esimerkiksi satoja osallistujia yhteen koonnut Startup Circus -tapahtuma, jossa perinteinen liikeideakilpailu yhdistyi taiteeseen. Tilaisuudessa taiteilijayrittäjät pitivät esityksiä, esittelivät taideteoksiaan ja kertoivat työskentelytavoistaan. Näin he rikkoivat mediassa vallalla olevaa menestyjän myyttiä, jossa yrittäjät ovat kiivenneet start-up-pyramidin huipulle burnoutien siivittämänä, ja tarjosivat keskusteluun toisenlaisen katsantokannan, joka voi parhaimmillaan laukaista hedelmällisiä ajatusketjuja.

Liiallista tavoitehakuisuutta voidaan vähentää myös yrittäjyyskoulutuksen sisällöissä (Koskinen 2019). Sen sijaan, että tarjotaan vain tietoa ja suunnitellaan tarkasti sisällöt, voi olla hyödyllistä tarjota yllykkeitä ja kulloisellakin hetkellä olennaista inspiraatiota. Inspiraation tarjoaminen edellyttää koulutussisältöjen joustavaa suunnittelua. Nopeasti muuttuvassa toimintaympäristössä koulutusprojektit toteutuvat harvoin, jos koskaan, täysin suunnitellusti. Tämä vaatii koulutusorganisaatioilta nopeaa reagointikykyä, ja edellyttää muutos- ja sopeutumiskykyä myös koulutuksen rahoittajilta. Palvelupakettien toiston sijaan täytyy uskaltaa kysyä koulutuksen kohdeyleisöltä, mitkä sen tarpeet ovat juuri kyseisellä hetkellä.
Pohdittavaksi jää se, millä tavoin voimme hyödyntää eri osallistujien mielissä syntyneitä rikkaita ajatuksia ja ideoita, jotka voivat olla hyvinkin erilaisia heidän kokemustaustastaan riippuen? Ja miten osaamme kommunikoida yrittäjyyskoulutuksen "hyödyistä", jos osallistujat itse ovat lopulta vastuussa siitä, mitä voivat "saada irti" kustakin tilaisuudesta ja valmennuksesta?

\section{HITAASTI JA HARPPAUKSIN ETEENPÄIN}

Milloin yrittäjyyskoulutus on onnistunut tavoitteessaan? Lasketaanko menestys syntyneiden yritysten määrässä vai tiedetäänkö se vasta vuosien päästä, kun nähdään, kuinka hyvin yritykset ovat pärjänneet? Voisiko menestystä mitatakin osallistujien henkisen hyvinvoinnin ja koetun elämänlaadun ja yhteiskuntaan integroitumisen näkökulmista?

Esimerkiksi yliopistoissa koulutuksesta valmistuneiden työllistymistä pidetään edelleen keskeisenä mittarina koulutuksen laadulle. Onko tämänkaltainen, yksilön henkisen pääoman kehittymisen huomiotta jättävä mittaristo merkityksellinen 2020-luvulla koulutuksen huippumaassa? Yrittäjyyteen liittyy tiettyjä erityispiirteitä, jonka myötä koulutuksen "hyvyyttä" pitää arvioida myös muutoin kuin ainoastaan numeerisilla mittareilla.

Yrittäjyyskoulutuksen peruskysymyksissä pitäisi tarkastella, miksi koulutusta alun perin annetaan ja mitä sillä tavoitellaan (Fayolle \& Gailly 2008; Kamovich \& Foss 2017). Koulutushankkeiden taustalla on usein tavoite lisätä yhdenvertaisuutta ja tarjota tasapuolisesti mahdollisuuksien itsensä toteuttamiseen ja menestymiseen sekä toisaalta ajatus siitä, että yrittäjyyden kautta voidaan tuottaa myös sosiaalista ja taloudellista hyvinvointia yhteiskuntaan. Yrittäjyydelle asetetuista odotuksista riippuu, mikä on hyödyllinen mittaustapa. Yksilölliset tavoitteet voivat olla keskenään hyvinkin erilaisia, ja kun yksi henkilö on tyytyväinen itsensä työllistämiseen, joku toinen ei koe onnistuneensa, ellei yritystoiminta kasva nopeasti. Yhteiskunnan näkökulmasta voidaan miettiä, mikä on oikea aikajänne tulosten tarkasteluun (Fayolle ym. 2006).

Yrittäjäksi ryhtyminen on pitkä prosessi. Sopivan markkinaraon tai mahdollisuuden tunnistamisen 
jälkeen pitää arvioida, kuinka tilaisuuteen voisi parhaiten tarttua ja lopulta ottaa askel yrittäjyyteen (Pryor ym. 2016). Yrittäjyyskouluttajan ja yrittäjäksi aikovan kannalta voi olla mielekästä mitata, kuinka yrittäjyys tulee vähitellen osaksi omaa elämäntarinaa ja identiteettiä, ja mitä tuntemuksia tämä herättää (Celuch ym. 2017).

Kouluttaja voivat itse arvioida koulutuksen laatua. MEGE-projektissa verrattiin koulutusta muihin tarjolla oleviin maahanmuuttajille tarjottuihin palveluihin (benchmark) ja kerättiin jatkuvasti palautetta koulutuksiin osallistuneilta henkilöiltä. Lisäksi hankkeen työpajoissa arvioitiin eri koulutusorganisaation välistä yhteistyötä ja sitä, kuinka projekti oli esimerkiksi kasvattanut tietoisuutta yrittäjyydestä ja sitä tukevista palveluista maahanmuuttajien keskuudessa.

Laadullisia mittareita hyödyntämällä voidaan tarkentaa kuvaa onnistumisista ja kipukohdista, joihin on syytä tarttua. Ennen kaikkea näin tuetaan myös yrittäjyyskoulutuksen eettisyyttä (Hytti, 2019). Yrittäjyyteen ei pitäisi missään oloissa kritiikittömästi kannustaa maahanmuuttajia kuten ei muitakaan ihmisryhmiä. Yrittäjyys ei välttämättä ole taloudellisesti paras vaihtoehto, ja se voi olla hyvin stressipitoinen valinta. Siksi on aika siirtyä yhtä yrittäjän muottia korostavasta sankaritarinasta kohti realismia, ja ymmärtää erilaisuutta sekä ainutlaatuisia ja paikoin rosoisia yrittäjyystarinoita.

Maahanmuuttajien yrittäjyyskoulutuksen on istuttava heidän elämäntilanteeseensa. Vaikka monen yrittään suunnitelmat ovat menneet covid-19-pandemian myötä uusiksi, osalle MEGE-projektiin osallistuneista yrittäjyys tarjosi turvaa ja jatkuvuutta, ja tuotti näin sekä henkistä, sosiaalista että taloudellista hyvinvointia.

Pitääkö yrittäjäksi tähtäävän maahanmuuttajan sitten elää yrittäjän elämä? Yksinäisyys ja uhma -teoksen sanotaan kuvaavan kirjailija Erno Paasilinnan omia kokemuksia. Hän kirjoittaa näin: "Kirjailijaksi ei synnytä. [--] On elettävä sellainen elämä, josta syntyy kirjailija”.

Ehdotamme, että vaikka yrittäjänä oleminen edellyttää tiettyjä taitoja ja tekoja, nämä eivät ole sisäsyntyisiä eivätkä sellaisia, joita voidaan istuttaa ihmiseen annostelemalla tiettyjä tietoja ja sisältöjä pedagogisesti taitavasti. Yrittäjäksi aikovan on kerättävä elämäänsä kokemuksia, joiden kautta hän voi tunnistaa ja vahvistaa yksilöllisiä kykyjään ja pystyy luomaan itselleen ympäristön, jossa on mahdollisuus kukoistaa ja onnistua. Mitä tämä itse kullekin tarkoittaa, voi vaihdella paljonkin.

Yrittäjyyskoulutusta tarjoavien toimijoiden kannalta on kuitenkin selvää, että taloudellisesti ja eettisesti kestäviä tuloksia saavutetaan tukemalla yrittäjyydestä kiinnostuneiden omaehtoista kehitystä, ja kulkemalla jonkin matkaa heidän rinnallaan.

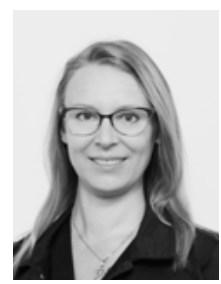

VIRVA SALMIVAARA

KTT, VTM, tutkijatohtori yrittäjyyden yksikkö Aalto-yliopiston kauppakorkeakoulu

(D) https://orcid.org/0000-00015481-848X

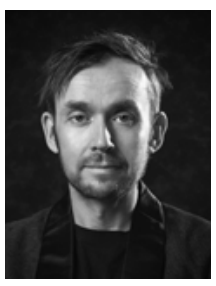

JUKKA-PEKKA HEIKKILÄ

KTT yrittäjyyden yksikkö Aalto-yliopiston kauppakorkeakoulu vieraileva tutkija Stanfordin yliopisto; Harvardin yliopisto

(iD https://orcid.org/0000-00022832-8345

Kiitämme kaikkia MEGE-projektiin osallistuneita maahanmuuttajia ja kouluttajia sekä projektin toteuttajia ja rahoittajia.

\section{VIITTEET}

1 https://m.youtube.com/results?search_query=esa+saarinen+filosofia+ja+systeemiajattelu 


\section{LÄHTEET}

Adecco (2017). The labour market integration of refugees white paper. A focus on Europe. The Adecco Group. https://www.adeccogroup.com/ wp-content/themes/ado-group/downloads/labourmarket-integration-of-refugees-focus-europe.pdf.

Anderson, A. R. \& Warren, L. (2011). The entrepreneur as hero and jester; enacting the entrepreneurial discourse. International Small Business Journal 29(6), 589-609.

Bechard, J. \& Gregoire, D. (2005). Entrepreneurship education research revisited: The case of higher education. Academy of Management Learning and Education 4(1), 22-43.

Celuch, K., Bourdeau, B. \& Winkel, D. (2017). Entrepreneurial identity: the missing link for entrepreneurship education. Journal of Entrepreneurship Education 20(2), 1-20.

Deloitte (2017). Talent displaced. The economic lives of Syrian refugees in Europe. https://www2.deloitte. com/content/dam/Deloitte/global/Documents/ About-Deloitte/talent-displaced-syrian-refugeeseurope.pdf.

Donnellon, A., Ollila, S. \& Middleton, K. W. (2014). Constructing entrepreneurial identity in entrepreneurship education. International Journal of Management Education 12(3), 490-499.

Duval-Couetil, N. (2013). Assessing the impact of entrepreneurship education programs: Challenges and approaches. Journal of Small Business Management 51(3), 394-409.

Edmondson, A. C. (1999). Psychological safety and learning behavior in work teams. Administrative Science Quarterly 44(2), 350-383.

Engel, Y., Noordijk, S., Spoelder, A. \& van Gelderen, M. (2019). Self-compassion when coping with venture obstacles: Loving-kindness meditation and entrepreneurial fear of failure. Entrepreneurship Theory and Practice. Online first. https://doi. org/10.1177/1042258719890991

Euroopan komissio. (2016). Evaluation and Analysis of Good Practices in Promoting and Supporting Migrant Entrepreneurship. Guide book. https:// ec.europa.eu/easme/sites/easme-site/files/documents/ guide_book_promoting_and_supporting_migrant_ entrepreneurship.pdf.

Fayolle, A. \& Gailly, B. (2008). From craft to science: Teaching models and learning processes in entrepreneurship education. Journal of European Industrial Training 32(7), 569-593.

Fayolle, A., Gailly, B. \& Lassas-Clerc, N. (2006). Assessing the impact of entrepreneurship education programmes: A new methodology. Journal of European Industrial Training 30(9), 701-720.
Ferry, T., Sidhu, I., Goyal, M. \& Fred-Ojala, A. (2018). Breaking the Zuckerberg Myth: Successful Entrepreneurs Have 10 Years of Prior Employment. IEEE International Conference on Engineering, Technology and Innovation (ICE/ITMC), Stuttgart, 1-7.

Fong, R., Busch, N. B., Armour, M., Heffron, L. C. \& Chanmugam, A. (2007). Pathways to self-sufficiency: Successful entrepreneurship for refugees. Journal of Ethnic \& Cultural Diversity in Social Work 16(1-2), 127-159.

Frazier, M. L., Fainshmidt, S., Klinger, R. L., Pezeshkan, A \& Vracheva, V. (2017). Psychological safety: A metaanalytic review and extension. Personnel Psychology 70(1), 113-165.

Gomez, C., Perera, B. Y., Wesinger, J. Y. \& Tobey, D. H. (2020). Immigrant entrepreneurs and community social capital: an exploration of motivations and agency. Journal of Small Business and Enterprise Development 27(4), 579-605.

Hytti, U. (2019). Yrittäjyyden edistämisen kiperät ja kriittiset kysymykset yliopistoissa. Aikuiskasvatus 39(2), 138-143. https://doi.org/10.33336/aik.82985

Hytti, U. \& Heinonen, J. (2013). Heroic and humane entrepreneurs: identity work in entrepreneurship education. Education + Training 55(8/9), 886-898.

Jensen, T. L. (2014). A holistic person perspective in measuring entrepreneurship education impactSocial entrepreneurship education at the Humanities. The International Journal of Management Education 12(3), 349-364.

Kamovich, U. \& Foss, L. (2017). In Search of Alignment: A Review of Impact Studies in Entrepreneurship Education. Education Research International 2, 1-15.

Kloosterman, R. C. (2010). Matching opportunities with resources: A framework for analysing (migrant) entrepreneurship from a mixed embeddedness perspective. Entrepreneurship and Regional Development 22(1), 25-45.

Koskinen, H. (2019). Yrittäjäyhteisön taika: Yrittäjyyden muotoutuminen korkeakoulujen yrittäjyystoiminnassa. Aikuiskasvatus 39(2), 108-121. https://doi.org/10.33336/aik.82984

Laine, L. \& Kibler, E. (2018). Towards a mythic process philosophy of entrepreneurship. Journal of Business Venturing Insights 9, 81-86.

Liñán, F., Ceresia, F. \& Bernal, A. (2018). Who Intends to Enroll in Entrepreneurship Education? Entrepreneurial Self-Identity as a Precursor. Entrepreneurship Education and Pedagogy 1(3), 222-242.

Luke, B., Verreynne, M. \& Kearins, K. (2007). Measuring the benefits of entrepreneurship at different levels of analysis. Journal of Management and Organization 13(4), 312-330. 
Ma, Z., Zhao, S., Wang, T. \& Lee, Y. (2013). An overview of contemporary ethnic entrepreneurship studies: themes and relationships. International Journal of Entrepreneurial Behavior and Research 19(1), 32-52.

Obschonka, M., Hahn, E. \& Bajwa, N. (2018).

Personal agency in newly arrived refugees: The role of personality, entrepreneurial cognitions and intentions, and career adaptability. Journal of Vocational Behavior 105, 173-184.

Pryor, C., Webb, J. W., Ireland, R. D. \& Ketchen, D. J. (2016). Toward an integration of the behavioral and cognitive influences on the entrepreneurship process. Strategic Entrepreneurship Journal 10(1), 21-42.

Rath, J. (2011). Promoting ethnic entrepreneurship in European cities, Publications Office of the European Union, Luxembourg. https://www.eurofound. europa.eu/sites/default/files/ef_publication/field_ef_ document/ef1138en.pdf.

Rigg, C. \& O'Dwyer, B. (2012). Becoming an entrepreneur: researching the role of mentors in identity construction. Education + Training 54(4), 319-329.

Sahin, M., Nijkamp, P., \& Suzuki, S. (2014). Contrasts and similarities in economic performance of migrant entrepreneurs. IZA Journal of Development and Migration 3(7).

Salmivaara, V., Martela, F., \& Heikkilä, J.-P. (2020). Radikaali psykologinen turvallisuus tilapäisorganisaation luovan ja tuloksellisen toiminnan mahdollistajana. Hallinnon tutkimus 3, 170-186.

Spigel, B. (2017). The relational organization of entrepreneurial ecosystems. Entrepreneurship Theory and Practice 41(1), 49-72. 